\title{
Determination of the reference genes for qRT-PCR normalization and expression levels of MAT genes under various conditions in Ulocladium
}

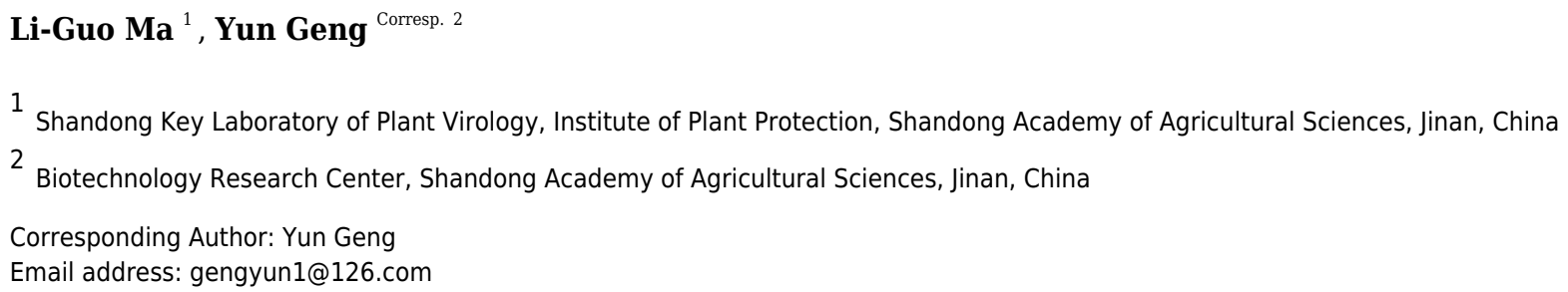

The genus Ulocladium is thought to be strictly asexual. One of the possible reasons for the lack of sexuality in Ulocladium species is the absence of the stimulus of environmental factors. Sexual reproduction in ascomycetes is controlled by a specific region in the genome referred to as mating-type locus (MAT) that consists of two dissimilar DNA sequences in the mating partners, termed MAT1-1 and MAT1-2 idiomorphs. To identify the response of MAT loci to environmental conditions, the mRNA transcription level of MAT1-1-1 and MAT1-2-1 genes was tested using qRT-PCR under different temperatures $\left(-20^{\circ} \mathrm{C},-10^{\circ} \mathrm{C}, 0{ }^{\circ} \mathrm{C}, 10^{\circ} \mathrm{C}, 20^{\circ} \mathrm{C}, 30^{\circ} \mathrm{C}\right.$ and $\left.40^{\circ} \mathrm{C}\right)$, culture medias (CM, OA, HAY, PCA, PDA and V8), photoperiods (24h light, 24h dark, $12 \mathrm{~h}$ light/12h dark, 10h light/14h dark and $8 \mathrm{~h}$ light/16h dark), and $\mathrm{CO}_{2}$ concentrations $(0.03 \%, 0.5 \%, 1 \%, 5 \%, 10 \%, 15 \%$ and $20 \%)$. For obtaining reliable results from qRT-PCR, the most stable internal control gene and optimal number of reference genes for normalization were determined under different treatments. The results showed that there is no universal internal control gene that is expressed at a constant level under different experimental treatments. In comparison to various incubation conditions, the relative expression levels of both MAT genes were significantly increased when fungal mycelia were grown on HAY culture media at $0-10{ }^{\circ} \mathrm{C}$ with a light/dark cycle, indicating that temperature, culture media, and light might be the key environmental factors for regulating the sexuality in Ulocladium. Moreover, MAT1-1-1 and MAT1-2-1 genes showed similar expression patterns under different treatments, suggesting that the two MAT genes might play an equally important role in the sexual evolutionary process. 


\section{Determination of the reference genes for $q R T-P C R$}

2 normalization and expression levels of $M A T$ genes under

3 various conditions in Ulocladium

4

5 Li-Guo $\mathrm{Ma}^{1}$ and Yun Geng ${ }^{2}$

6

$7{ }^{1}$ Shandong Key Laboratory of Plant Virology, Institute of Plant Protection, Shandong Academy

8 of Agricultural Sciences, Jinan, 250100, China

92 Biotechnology Research Center, Shandong Academy of Agricultural Sciences, Jinan, 250100, 10 China

11

12 Corresponding Author:

13 Yun Geng

14202 Gongyebei Road, Jinan, Shandong, 250100, China

15 Email address: gengyun1@126.com

16

17

18

19

20

21

22

23

24

25

26

27

28

29

\section{ABSTRACT}

The genus Ulocladium is thought to be strictly asexual. One of the possible reasons for the lack of sexuality in Ulocladium species is the absence of the stimulus of environmental factors. Sexual reproduction in ascomycetes is controlled by a specific region in the genome referred to as mating-type locus $(M A T)$ that consists of two dissimilar DNA sequences in the mating partners, termed MAT1-1 and MAT1-2 idiomorphs. To identify the response of MAT loci to environmental conditions, the mRNA transcription level of MAT1-1-1 and MAT1-2-1 genes was tested using qRT-PCR under different temperatures $\left(-20{ }^{\circ} \mathrm{C},-10^{\circ} \mathrm{C}, 0{ }^{\circ} \mathrm{C}, 10^{\circ} \mathrm{C}, 20^{\circ} \mathrm{C}, 30^{\circ} \mathrm{C}\right.$ and $40^{\circ} \mathrm{C}$ ), culture medias (CM, OA, HAY, PCA, PDA and V8), photoperiods (24h light, $24 \mathrm{~h}$ dark, $12 \mathrm{~h}$ light/12h dark, $10 \mathrm{~h}$ light/14h dark and $8 \mathrm{~h}$ light/16h dark), and $\mathrm{CO}_{2}$ concentrations $(0.03 \%, 0.5 \%, 1 \%, 5 \%, 10 \%, 15 \%$ and $20 \%)$. For obtaining reliable results from qRT-PCR, the most stable internal control gene and optimal number of reference genes for normalization were determined under different treatments. The results showed that there is no universal internal control gene that is expressed at a constant level under different experimental treatments. In 
31 comparison to various incubation conditions, the relative expression levels of both $M A T$ genes

32 were significantly increased when fungal mycelia were grown on HAY culture media at $0-10{ }^{\circ} \mathrm{C}$

33 with a light/dark cycle, indicating that temperature, culture media, and light might be the key

34 environmental factors for regulating the sexuality in Ulocladium. Moreover, MAT1-1-1 and

35 MAT1-2-1 genes showed similar expression patterns under different treatments, suggesting that

36 the two MAT genes might play an equally important role in the sexual evolutionary process.

37

\section{INTRODUCTION}

It has been estimated that there are at least 1.5 million fungi species worldwide, which is six times higher than plants (Hawksworth, 2001). Hyphomycetes, a major taxon of fungi, including more than 450 genera, are widely distributed in land, sea, air, and soil, which account for more than $30 \%$ of the fungal kingdom (Hawksworth, Sutton \& Ainsworth, 1983; Kirk et al., 2008; http://www.indexfungorum.org). However, no sexual stage has been identified in most of hyphomycetes. For more than 450 genera of hyphomycetes, Hyphomycetales, Dematiaceous hyphomycetes, teleomorphs were found in only 67 genera.

Ulocladium (Preuss, 1851) is an anamorphic genus of the Pleosporaceae (Dothideomycetes, Kirk et al., 2008). Some species of Ulocladium are often found as pathogens or endophytes of living plants, and act as saprobes that play vital role in the decomposition and recycling of materials in natural ecosystems (Zitter \& Hsu, 1990; Vannini \& Vettraino, 2000). Teleomorphs of many closely allied genera of Ulocladium have been found, such as Stemphylium Wallr, Alternaria Nees, and Nimbya E.G. Simmons. However, Ulocladium species are thought to be strictly asexual.

Sexual reproduction in ascomycetes is controlled by mating-type locus (MAT) (Coppin et al., 1997; Turgeon, 1998) that consists of two idiomorphs, termed MAT1-1 and MAT1-2, with identical flanking regions and dissimilar DNA sequences (Turgeon et al., 1993; Cozijnsen \& Howlett, 2003). MAT1-1-1 and MAT1-2-1 encode proteins containing an alpha domain and a HMG (high mobility group) domain, respectively (Turgeon, 1998). MAT genes have been characterized in many filamentous ascomycetes (Inderbitzin et al., 2005; Groenewald et al., 2006; Santos, Correia \& Phillips, 2010; Bolton et al., 2012), and the MAT1-1-1 and MAT1-21 genes have been obtained from 26 Ulocladium species (Geng et al., 2014). Ulocladium strains possess both MAT1-1-1 and MAT1-2-1 genes as observed in homothallic filamentous 
62 Ascomycetes. However, unlike the majority of homothallic fungi, MAT1-1 and MAT1-2

63 idiomorphs are not closely linked and flanked by identical sequences in Ulocladium species. It

64 has been reported that $U$. botrytis MAT genes have the ability to induce sexual recombination

65 in Cochliobolus heterostrophus (Wang et al., 2017), indicating that MAT locus might be

66 functional in Ulocladium, and the expression levels of MAT genes might directly affect sexual

67 development in fungi. Thus, the Ulocladium species has the potential for sexual reproduction.

68 However, as yet, no sexual stage has been identified in the whole genus of Ulocladium. One of

69 the possible reasons for the lack of sexuality in Ulocladium species is the absence of

70 environmental stimuli, including medium, light, temperature, atmospheric gases, and others,

71 which could influence the sexual development.

72 Environmental factors have great influences on sexual development of filamentous fungi,

73 as ascospore production requires special conditions, and different ascomycete isolates show

74 variations in response to identical incubation conditions. For instance, teleomorphs of many

75 putatively asexual fungi have been found under controlled conditions. Perithecium formation

76 was favored at $20^{\circ} \mathrm{C}$ with a 16-h daily photoperiod in Mycosphaerella pinodes (Roger \& Tivoli,

77 1996). For Pyrenophora tritici-repentis, a large number of asci and ascospores were produced by

78 incubation on senescent leaves in continuous darkness for 12 days followed by a 12-h

79 photoperiod at $15^{\circ} \mathrm{C}$ (Friesen et al., 2003). Several isolates of Stemphylium could produce

80 mature ascocarps on hay decoction agar, 20\% V-8 juice agar or weak potato-carrot agar, within

81 cycles ranging from a few months to a year or more (Simmons, 1969). Gaeumannomyces

82 graminis var. tritici that is thought to be strictly asexual in nature could produce asci and

83 ascospores adequately in the sterile culture medium with dark/light $(12 \mathrm{~h} / 12 \mathrm{~h})$ at 15 to $20{ }^{\circ} \mathrm{C}$ for

$8472 \mathrm{~h}$ (Holden \& Hornby, 1981). The ability of sexual reproduction in Candida albicans was

85 enhanced with high temperature, high $\mathrm{CO}_{2} / \mathrm{O}_{2}$, and darkness (Ramírez-Zavala et al., 2008;

86 Whiteway, 2009).

87 Quantitative real-time reverse transcription polymerase chain reaction (qRT-PCR) is a

88 valuable tool to quantify the transcript expression levels of a gene in the cells of different tissues

89 under specific experimental conditions. To remove the non-biological variation caused by

90 experimental deviations, inhibitory compounds, RNA isolation or reverse transcriptase efficiency,

91 it is necessary to appropriate normalize the qRT-PCR data. The most common way to normalize

92 the data generated by qRT-PCR is to use proper internal reference genes (Zitter \& Hsu, 1990). 
93 Many housekeeping genes (HKGs), such as $\beta$-actin (ACT), glyceraldehyde-3-phosphate

94 dehydrogenase (GAPDH), $\beta$-tubulin (Tub-b), and 18S ribosomal RNA were frequently used as

95 internal controls for gene expression analysis. However, several studies have indicated that

96 expression levels of such reference genes also vary even under the same experimental conditions

97 (Suzuki, Higgins \& Crawford, 2000; Lee et al., 2002). In general, there is no universal internal

98 control gene that is expressed at a constant level under different experimental conditions (Peters

99 et al., 2007; Mitter et al., 2009). Therefore, to avoid erroneous results, the validity of candidate

100 reference genes under specific experimental conditions must be determined.

101 In this study, to find the most stable internal control gene (s) for normalization of qRT-PCR

102 in Ulocladium under different environmental conditions, the expression of seven frequently used

103 HKGs, including Actin, $\beta$-tubulin, EF-1 $\alpha, G A P D H, R L 13, T B P$, and $U B C$ were assessed. In

104 addition, to identify the response of MAT loci to environmental conditions in Ulocladium, the

105 mRNA transcription levels of MAT1-1-1 and MAT1-2-1 genes were analyzed.

106

107 MATERIALS \& METHODS

108 Ulocladium strains and growth conditions

109 The strains of U. botrytis (CBS 198.67) and Stemphylium botryosum (teleomorph Pleospora

$110 \operatorname{tarda})(\mathrm{CBS} 714.68)$ were used for test. Owing that Ulocladium is closely allied to the genus

111 Stemphylium Wallr, the teleomorph of Stemphylium botryosum was chosen as sexual

112 representative. All samples were obtained from the culture collection of the Westerdijk Institute,

113 Utrecht, The Netherlands. For each strain, cultures were grown on potato-carrot agar (PCA; $20 \mathrm{~g}$

114 white potato boiled and filtered, $20 \mathrm{~g}$ carrot boiled and filtered, $20 \mathrm{~g}$ agar, $1 \mathrm{~L}$ distilled water) at

$11525^{\circ} \mathrm{C}$ for ten days.

116 Treatments

117 For temperature treatments, small squares of fungal mycelia were placed in the middle of the

118 petri dishes (9 $\mathrm{cm}$ in diameter) containing PCA medium, and the cultures were grown at $25^{\circ} \mathrm{C}$ for

11910 days. Cultures were then exposed to seven different temperature treatments: $-20^{\circ} \mathrm{C},-10^{\circ} \mathrm{C}$,

$1200^{\circ} \mathrm{C}, 10^{\circ} \mathrm{C}, 20^{\circ} \mathrm{C}, 30^{\circ} \mathrm{C}$, and $40^{\circ} \mathrm{C}$, with a daily photoperiodic cycle of $14 \mathrm{~h}$ light and $10 \mathrm{~h}$ dark

121 for seven days. Fungal mycelia were scraped from the surface of the agar firstly, and then stored

122 at $-80^{\circ} \mathrm{C}$ until RNA extraction. Three biological replicates were used for each condition. 
123

124

125

126

127

128

129

130

131

132

133

134

135

136

137

138

139

140

141

142

143

144

145

146

147

148

149

150

151

152

153

For medium treatments, small squares of fungal mycelia were placed in the middle of the petri dishes ( $9 \mathrm{~cm}$ in diameter) containing PCA, PDA (200 g white potato, $20 \mathrm{~g}$ glucose, $20 \mathrm{~g}$ agar, $1 \mathrm{~L}$ distilled water), CMA (200 g corn meal, $20 \mathrm{~g}$ agar, $1 \mathrm{~L}$ distilled water), HAY (10 g hay, $20 \mathrm{~g}$ agar, $1 \mathrm{~L}$ distilled water), OA (100 g oatmeal, $20 \mathrm{~g}$ agar, $1 \mathrm{~L}$ distilled water) and V8 (150 ml V8 juice, $1.6 \mathrm{~g} \mathrm{CaCO}_{3}, 20 \mathrm{~g}$ agar, $1 \mathrm{~L}$ distilled water) medium separately, and the cultures were grown at $10^{\circ} \mathrm{C}$ in a $12: 12$ light dark regime for two weeks. Fungal mycelia were scraped from the surface of the agar firstly, and then stored at $-80^{\circ} \mathrm{C}$ until RNA extraction. Three biological replicates were used for each condition.

For photoperiod treatments, small squares of fungal mycelia were placed in the middle of the petri dishes ( $9 \mathrm{~cm}$ in diameter) containing HAY, and then exposed to different photoperiods, respectively: $24 \mathrm{~h}$ light, $24 \mathrm{~h}$ dark, $12 \mathrm{~h}$ light: $12 \mathrm{~h}$ dark, 10h light: $14 \mathrm{~h}$ dark, $8 \mathrm{~h}$ light: $16 \mathrm{~h}$ dark, at $10^{\circ} \mathrm{C}$ for two weeks. Fungal mycelia were firstly scraped from the surface of the agar, and then stored at $-80^{\circ} \mathrm{C}$ until RNA extraction. Three biological replicates were used for each condition.

For $\mathrm{CO}_{2}$ treatments, small squares of fungal mycelia were placed in the middle of the petri dishes $\left(9 \mathrm{~cm}\right.$ in diameter) containing HAY, and the cultures were grown at $25^{\circ} \mathrm{C}$ for 10 days. Cultures were then respectively exposed to seven $\mathrm{CO}_{2}$ concentrations: $0.03 \%, 0.5 \%, 1 \%, 5 \%$, $10 \%, 15 \%$, and $20 \%$, at $10^{\circ} \mathrm{C}$ with a light/dark cycle for 7 days. Fungal mycelia were firstly scraped from the surface of the agar, and then stored at $-80^{\circ} \mathrm{C}$ until RNA extraction. Three biological replicates were used for each condition.

\section{Total RNA extraction and reverse transcription}

Mycelia of $U$. botrytis and ascomata of $S$. botryosum were collected for total RNA extraction. Total RNA was extracted with Trizol reagent (Invitrogen) according to the manufacturer's instructions, followed by RNase-free DNase treatment (Takara, Japan). The RNA concentrations were quantified by a spectrophotometer (spectra-Max plus 384), and the RNA integrity was assessed by $1 \%$ agarose gel electrophoresis. RNA samples were used as template for PCR amplifications to confirm that no genomic DNA contamination appeared in the samples using primers 5'-CCACCATCCACTCTTACACCG-3' and 5'-TGACCTTGCCGACAGCCT-3'. The SuperScript First-Strand Synthesis System (Invitrogen) for RT-PCR is optimized to synthesize first-strand of cDNA use with $3 \mu \mathrm{g}$ of total RNA according to manufacturer's instructions. The obtained cDNA samples were then diluted at 1:5 in nuclease-free water. The reverse transcriptions were performed in triplicate for all treatment conditions. 
154 qRT-PCR

155 qRT-PCR was performed using ICycler IQ real-time PCR detection system (Bio-Rad) and SYBR 156 primer Script RT-PCR kit (TakaRa) with the following cycling parameters: an initial 157 denaturation step at $95^{\circ} \mathrm{C} 10 \mathrm{~min}, 45$ cycles of $10 \mathrm{~s}$ at $95{ }^{\circ} \mathrm{C}, 55 \mathrm{~s}$ at $60^{\circ} \mathrm{C}$, and finally $45 \mathrm{~s}$ at 72 $158{ }^{\circ} \mathrm{C}$. For qRT-PCR reaction mixtures contained $12.5 \mu \mathrm{l}$ of the $2 \times \mathrm{SYBR}$ Green PCR master mix 159 (TakaRa), $800 \mathrm{nM}$ of each primer and $2.5 \mu 1$ of cDNA template in a total volume of $25 \mu 1$. The 160 primers were designed using Primer Express 3.0 for qRT-PCR. Three replicates were performed 161 for all reactions, and negative controls were included for each gene. Threshold cycle (CT) values 162 were exported to Microsoft Excel, and the fold changes of each gene were calculated using $2^{-\Delta \Delta C t}$ 163 equation.

164 Determining expression stability of reference genes

165 Average gene expression stability (M) and pairwise variation (V) calculated by geNorm (version 166 3.5) program. Genes with the lowest $M$ values have the most stable expression (Vandesompele et 167 al., 2002). Furthermore, normalization factors (NFn) and $\mathrm{Vn} / \mathrm{Vn}+1$ value were calculated to 168 estimate the optimal number of controls used in each single experiment.

169 Statistical analysis

170 Statistical analyses were performed by analysis of variance (ANOVA) using SPSS v. 13.0

171 (SPSS, United States).

172

173 RESULTS

\section{Selection of HKGs}

175 Although morphological and phylogenetic analysis of Ulocladium has been studied well, little 176 effort has been made for gene expression studies using qRT-PCR. Seven most commonly used 177 HKGs in other ascomycetes were selected as candidate reference genes in Ulocladium: $\beta$-actin 178 (Actin), $\beta$-tubulin (Tub-b), translation elongation factor $1 \alpha(E F-1 \alpha)$, glyceraldehyde-3-phosphate 179 dehydrogenase $(G A P D H), 60$ S ribosomal protein L13 (RL13), TATA box binding protein (TBP), 180 and ubiquitin-conjugating enzyme $(U B C)$. All the primer sets were confirmed by the appearance 181 of a single, dominant peak in the qRT-PCR dissociation curve analyses (Fig. S1), indicating the 182 specificity of the qRT-PCR reactions.

183 Ranking the expression stability of reference genes under different treatments 
184 The geNorm software was then used to compare the transcription levels of the selected seven

185 candidate reference genes and identify the most stable gene under different experimental 186 conditions. The average expression stability (M) values of the selected genes were ranked. The

187 results showed that there is no universal internal control gene that is expressed at a constant level 188 under different experimental treatments.

189 For temperature treatments, all candidate reference genes that reached high expression 190 stability showed relative low M values $(<1)$. EF-1 $\alpha$ and Actin were the most stable genes, while $191 R L 13$ was the most unstable gene. The ranking of the expression stability of selected genes in 192 different temperatures as follows: $E F-1 \alpha$, Actin $>G A P D H>U B C>T B P>\beta$-tubulin $>$ RL13 (Fig. 193 1A).

194 For medium treatments, the $\mathrm{M}$ values for all investigated genes were lower than 1.5. TBP 195 and EF-1 $\alpha$ were ranked as the most stable reference genes and Actin was the most unstable gene. 196 The ranking of the expression stability for different medium treatments as follows: $T B P, E F$ $1971 \alpha>G A P D H>\beta$-tubulin $>U B C>R L 13>\operatorname{Actin}$ (Fig. 1B).

198 For photoperiod treatments, the $\mathrm{M}$ values for all supposed reference genes were lower than 199 1.5. The most stable genes were $G A P D H$ and $E F-1 \alpha$. The ranking of the expression stability for 200 different photoperiod treatments as follows: GAPDH, EF-1 $\alpha>$ Actin $>T B P>\beta$-tubulin $>U B C>$ $201 R L 13$ (Fig. 1C).

202 For $\mathrm{CO}_{2}$ treatments, the $\mathrm{M}$ values for all investigated genes were lower than 1.5. EF-1 $\alpha$ and $203 G A P D H$ were the best-ranked genes, and $R L 13$ was the worst scoring gene. The ranking of the 204 expression stability for different $\mathrm{CO}_{2}$ treatments as follows: $E F-1 \alpha, G A P D H>A c t i n>T B P>\beta$ 205 tubulin $>U B C>R L 13$ (Fig. 1D).

206 To estimate the optimal number of reference genes for normalization under different 207 conditions, normalization factors (NFn) and $\mathrm{Vn} / \mathrm{Vn}+1$ value were calculated. The default cut-off 208 threshold is 0.15 (Vandesompele et al., 2002), indicating it is unnecessary to select an additional 209 reference gene when $\mathrm{Vn} / \mathrm{Vn}+1$ below 0.15. As shown in Fig. 2, two control genes for 210 'photoperiods' (Fig. 2C), three reference genes for ' $\mathrm{CO}_{2}$ concentrations' (Fig. 2D), and the four 211 most stably expressed genes for other treatments (Fig. 2A and B) were required for reliable 212 normalization of qPCR data.

213 Transcriptional levels of the $\boldsymbol{M A T}$ genes under different treatments 
214 For temperature treatments, the transcription levels of MAT1-1-1 and MAT1-2-1 genes were 215 investigated at $10^{\circ} \mathrm{C}$ intervals from -20 to $40^{\circ} \mathrm{C}$. The transcription levels of $M A T$ genes gradually 216 increased from -20 to $0^{\circ} \mathrm{C}$, and then eventually reached a peak at $10^{\circ} \mathrm{C}$ (Fig. 3). No significant 217 differences were observed between $0^{\circ} \mathrm{C}$ and $10^{\circ} \mathrm{C}$. These results showed that the expression of $218 M A T$ genes was induced at $0-10^{\circ} \mathrm{C}$.

219 For medium treatments, the MAT1-1-1 and MAT1-2-1 transcription levels of mycelia for 220 Ulocladium on different kinds of culture medias (CM, OA, HAY, PCA, PDA, V8) were tested. 221 MAT genes showed the highest transcription levels on HAY media, and did not show obvious 222 difference among the other culture medias (Fig. 4). The nutritional value of the HAY is the 223 lowest relative to the remaining media, suggesting that the nutrient-poor culture conditions could 224 cuase a significant increase in the expression of MAT genes.

For photoperiod treatments, the transcription levels of MAT1-1-1 and MAT1-2-1 genes were 226 investigated when were exposed to different photoperiods (24h light, 24h dark, $12 \mathrm{~h} \mathrm{light:12 \textrm {h }}$ dark, $10 \mathrm{~h}$ light:14h dark, $8 \mathrm{~h}$ light:16h dark). The expression of MAT genes with a light/dark 228 cycle was obviously higher than those of in other photoperiod treatments (Fig. 5). These results 229 indicated that $M A T$ loci could be activated by a light/dark cycle.

For $\mathrm{CO}_{2}$ treatments, the transcription levels of MAT1-1-1 and MAT1-2-1 genes were tested 231 when were exposed to different $\mathrm{CO}_{2}$ concentrations $(0.03 \%, 0.5 \%, 1 \%, 5 \%, 10 \%, 15 \%$, and 232 20\%). The transcription levels of $M A T$ genes remain unchanged after many repetitions (Fig. 6), 233 indicating that the $M A T$ expression could not be triggered by $\mathrm{CO}_{2}$.

Overall, the relative expression levels of both $M A T$ genes were significantly increased on HAY culture media at $0-10{ }^{\circ} \mathrm{C}$ with a light/dark cycle, indicating that the temperature, culture media, and light are the key environmental factors that affect the sexual development of Ulocladium. Similar expression patterns for MAT1-1-1 and MAT1-2-1 genes were found, suggesting that the two $M A T$ genes might play an equally important role in the sexual process. Moreover, the expression levels of Stemphylium botryosum MAT genes are significantly higher than those of $U$. botrytis, indicating that environmental factors alone are insufficient to induce sexual progeny for Ulocladium.

242

\section{DISCUSSION}


244 The qRT-PCR is now increasingly becoming the method of choice for accurate and sensitive 245 quantification of transcript expression levels. For valid qRT-PCR analysis, selection of 246 appropriate internal control genes for accurate normalization is required. However, the 247 expression of reference genes was instable under different experimental conditions, and the 248 expression patterns of the same reference varied in different fungal species. Thus, it is necessary 249 to determine the validity of candidate reference genes before normalization. Moreover, 250 quantitative analysis of gene expression should be related to several housekeeping genes in 251 252 253 254 255 256 257 258 259 260 261 262 263 264 265 266 267 268 269 270 271 272 273 274 parallel (Schmid et al., 2003), thus it is important to determine the optimal number of internal control genes required for accurate data normalization.

Actin, Tub-b,EF-1 $\alpha, G A P D H, R L 13, T B P$ and $U B C$ were found as most reliable HKGs for normalization of qRT-PCR data in many ascomycetes. However, it remained unclear whether these traditionally used reference genes are in fact the best possible choices for normalizing gene expression data in Ulocladium. To get reliable results from qRT-PCR, the most stable internal control genes, as well as the optimal number of reference genes for normalization were determined under temperature, medium, photoperiod, and $\mathrm{CO}_{2}$ treatments in Ulocladium. Consistent with previous studies, our results showed that there was no universal internal control gene that is expressed at a constant level under different experimental treatments (Suzuki, Higgins \& Crawford, 2000; Lee et al., 2002; Boxus, Letellier \& Kerkhofs, 2005).

Sexual reproduction could enhance the adaptability to environmental stress, which plays a prominent role in the evolution and continuation of species (Ashton \& Dyer, 2016). Sexual recombination is dominant in harsh habitats, including desiccation, high temperatures, fungicides and so on (Bowden \& Leslie, 1999, Dyer \& O'Gorman, 2012). Asexual lineages were thought to be evolutionary dead ends (Wik, Karlsson \& Johannesson, 2008), though they could complete population spread in a short time. However, the sexual stage of Ulolcladium has not been found yet. One of the possible reasons for the absence of sex in Ulocladium species is the lack of suitable environmental conditions influencing sexual development.

Environmental factors play an important role in regulating sexual differentiation and development of fungi. Hawker (1966) systematically discussed the effects of environmental conditions on the sexual reproduction of filamentous ascomycetes, and proposed that the environment suitable for mycelia development or asexual reproduction are not necessarily adapt to sexual cycle and the later development of teleomorphs. In recent years, mycologists have 
275 discovered the teleomorphs in several filamentous ascomycete species, which were thought to be 276 strictly asexual from Antarctica, Arctic, snow-covered mountains, nutrient-poor salt lakes, 277 deserts and plateau areas. Moreover, a few putatively asexual species have been successfully 278 induced teleomorphs in artificial stress conditions (poor nutrition, low temperature, strong 279 ultraviolet light, and high $\mathrm{CO}_{2} / \mathrm{O}_{2}$ ) (Simmons \& Roberts, 1993; Câmara, O'Neill \& Van Berkum, 280 2002). Environmental stresses may serve as a trigger to induce the expression of MAT genes, and 281 the activated mating signaling could then promote the sexual evolution and development of 282 asexual hyphomycetes.

283 Temperature, nutritional environments, photoperiod and $\mathrm{CO}_{2}$ concentrations have 284 prominent effect on the sexual recombination of filamentous ascomycetes (Swart et al., 2001; 285 Klich, 2002; Dyer \& $O^{\prime}$ Gorman, 2012). It has been found that $10-15^{\circ} \mathrm{C}$ was favorable for the 286 formation of apothecium in Monilinia (Casals et al., 2010), and the optimum temperature for 287 sexual reproduction of Aspergillus fumigatus was $30^{\circ} \mathrm{C}\left(O^{\prime}\right.$ Gorman, Fuller \& Dyer, 2008). Low 288 concentrations of carbon or nitrogen can promote sexual reproduction of filamentous 289 ascomycetes (Han et al., 1994; Han et al., 2003). Gelasinospora reticulospora and Alternaria 290 species could both produce a large number of perithecia under the light or dark conditions (Simmons \& Roberts, 1993; Chamberlain \& Ingram, 1997). In addition, on solid media, the number of asci improved significantly with increasing $\mathrm{CO}_{2}$ concentration in Aspergillus nidulans (Zonneveld, 1988). For Ulocladium species, extensive mating experiments were performed to induce sexual recombination under different temperatures, culture medias, photoperiods, and $\mathrm{CO}_{2}$ concentrations. No reproductive structures were observed despite the long incubation period 296 of more than six months.

Though the teleomorph formation has never been successful, we found that the transcription levels of Ulocladium MAT1-1-1 and MAT1-2-1 genes were up-regulated on HAY culture media at $0-10^{\circ} \mathrm{C}$ with a light/dark cycle. $M A T$ genes that are the key regulators for sexuality in filamentous ascomycetes are functional in Ulocladium (Geng et al., 2014; Wang et al., 2017), which could be activated by several environmental cues, and then control the sexual development in fungi. In addition, though specific environmental conditions can promote the expression of MAT genes of this genus, compared to Stemphylium botryosum, the significantly lower levels suggesting that environmental factors alone are insufficient to induce sexual 305 progeny. Further studies should be taken to reveal the key regulatory networks related to fungal 
306 reproduction by multi-omics analysis, and clarify the role of environmental factors in sexual 307 development.

308

\section{CONCLUSIONS}

310 In this study, the most stable internal control gene and optimal number of reference genes for

311 normalization were determined under temperature, medium, photoperiod, and $\mathrm{CO}_{2}$ treatments in

312 Ulocladium. In comparison to various incubation conditions, the relative expression levels of

313 both $M A T$ genes were significantly increased when fungal mycelia were grown on HAY culture

314 media at $0-10{ }^{\circ} \mathrm{C}$ with a light/dark cycle, indicating that temperature, culture media, and light

315 might be the key environmental factors that affect the sexual development of Ulocladium.

316

\section{ACKNOWLEDGEMENTS}

318 We thank the herbarium of the Westerdijk Institute for providing some valuable isolates in this study. We express gratitude to Dr. Xiuguo Zhang (Shandong Agricultural University) for his valuable comments and suggestions.

321

\section{REFERENCES}

323

324

325

326

327

328

329

330

331

332

333

334 335

Ashton GD, Dyer PS. 2016. Sexual development in fungi and its uses in gene expression systems. In: Schmoll M, Dattenböck C, ed. Gene expression systems of fungi: Applications and advancements. Switzerland: Springer International Publishing, 335-350.

Bolton MD, Secor GA, Rivera V, Weiland JJ, Rudolph K, Birla K, Rengifo J, Campbell LG. 2012. Evaluation of the potential for sexual reproduction in field populations of Cercospora beticola from USA. Fungal Biology 116:511-521.

Bowden RL, Leslie JF. 1999. Sexual recombination in Gibberella zeae. Phytopathology 89(2):182-188.

Boxus M, Letellier C, Kerkhofs P. 2005. Real Time RT-PCR for the detection and quantitation of bovine respiratory syncytial virus. Journal of Virological Methods 125(2):125-130.

Câmara MP, O'Neill NR, Van Berkum P. 2002. Phylogeny of Stemphylium spp. based on ITS and glyceraldehyde-3-phosphate dehydrogenase gene sequences. Mycologia 94(4):660672. 
336

337

338

339

340

341

342

343

344

345

346

347

348

349

350

351

352

353

354

355

356

357

358

359

360

361

362

363

364

365

366

Casals C, Teixidó N, Viñas I, Cambray J, Usall J. 2010. Control of Monilinia spp. on stone fruit by curing treatments. Part II: The effect of host and Monilinia spp. variables on curing efficacy. Postharvest Biology and Technology 56(1):26-30.

Chamberlain M, Ingram DS. 1997. The balance and interplay between asexual and sexual reproduction in fungi. Advances in Botanical Research 24:71-87.

Coppin E, Debuchy R, Arnaise S, Picard M. 1997. Mating types and sexual development in filamentous ascomycetes. Microbiology and Molecular Bioogyl Reviews 61(4):411-428.

Cozijnsen AJ, Howlett BJ. 2003. Characterisation of the mating-type locus of the plant pathogenic ascomycete Leptosphaeria maculans. Current Genetics 43(5):351-357.

Dyer PS, O'Gorman CM. 2012. Sexual development and cryptic sexuality in fungi: Insights from Aspergillus species. FEMS Microbiology Reviews 36(1):165-192.

Friesen T, Ali S, Stack R, Francl L, Rasmussen J. 2003. Rapid and efficient production of the Pyrenophora tritici-repentis teleomorph. Canadian Journal of Botany-Revue 81(8):890895.

Geng Y, Li Z, Xia LY, Wang Q, Hu XM, Zhang XG. 2014. Characterization and phylogenetic analysis of the mating-type loci in the asexual ascomycete genus Ulocladium. Mycologia 106(4):649-665.

Groenewald M, Groenewald JZ, Harrington TC, Abeln EC, Crous PW. 2006. Mating type gene analysis in apparently asexual Cercospora species is suggestive of cryptic sex. Fungal Genetics and Biology 43:813-825.

Han DM, Han YJ, Chae KS, Jahng KY. 1994. Effect of various carbon sources on the development of Aspergillus nidulans with velA + or velA1 allele. The Korean Journal of Mycology 22:332-332.

Han KH, Lee DB, Kim JH, Kim MS, Han KY, Kim WS, Park YS, Kim HB, Han DM. 2003. Environmental factors affecting development of Aspergillus nidulans. The Korean Journal of Microbiology 41(1):34-40.

Hawker LE. 1966. Fungi: an introduction. London: Hutchinson University Library.

Hawksworth DL, Sutton BC, Ainsworth GC. 1983. Ainsworth \& Bisby's Dictionary of the Fungi. 7th Ed. Commonwealth Mycological Institute, Kew, Surrey, England. 1-445.

Hawksworth DL. 2001. The magnitude of fungal diversity: The 1.5 million species estimate revisited. Mycological Research 105(12):1422-1432. 
367

368

369

370

371

372

373

374

375

376

377

378

379

380

381

382

383

384

385

386

387

388

389

390

391

392

393

394

395

396

397

Holden M, Hornby D. 1981. Methods of producing perithecia of Gaeumannomyces graminis and their application to related fungi. Transactions of the British Mycological Society 77(1):107-118.

Inderbitzin P, Harkness J, Turgeon BG, Berbee ML. 2005. Lateral transfer of mating system in Stemphylium. Proceedings of the National Academy of Sciences of The United States of America 102:11390-11395.

Kirk P, Cannon P, Minter D, Stalpers J. 2008. Dictionary of the Fungi 10th edn. CABI Bioscience. Wallingford, UK.

Klich MA. 2002. Biogeography of Aspergillus species in soil and litter. Mycologia 94(1):21-27.

Lee PD, Sladek R, Greenwood CM, Hudson TJ. 2002. Control genes and variability: Absence of ubiquitous reference transcripts in diverse mammalian expression studies. Genome Research 12(2):292-297.

Mitter K, Kotoulas G, Magoulas A, Mulero V, Sepulcre P, Figueras A, et al. 2009. Evaluation of candidate reference genes for qPCR during ontogenesis and of immunerelevant tissues of European seabass (Dicentrarchus labrax). Comparative Biochemistry and Physiology 153:340e7.

O'Gorman CM, Fuller HT, Dyer PS. 2008. Discovery of a sexual cycle in the opportunistic fungal pathogen Aspergillus fumigatus. Nature 457(7228):471-474.

Peters IR, Peeters D, Helps CR, Day MJ. 2007. Development and application of multiple internal reference (housekeeper) gene assays for accurate normalisation of canine gene expression studies. Veterinary Immunology and Immunopathology 117:55e66.

Preuss C. 1851. Die Pilze Deutschlands. Heft. 30. In Jacob Sturm's Deutschlands Flora, Abt. 3. Sturm JW, Nürnberg, Germany.

Ramírez-Zavala B, Reuß O, Park Y-N, Ohlsen K, Morschhäuser J. 2008. Environmental induction of white-opaque switching in Candida albicans. PLoS Pathogens 4(6):e1000089.

Roger C, Tivoli B. 1996. Effect of culture medium, light and temperature on sexual and asexual reproduction of four strains of Mycosphaerella pinodes. Mycological Research 100(3):304306.

Santos JM, Correia VG, Phillips AJL. 2010. Primers for mating-type diagnosis in Diaporthe and Phomopsis: Their use in teleomorph induction in vitro and biological species definition. Fungal Biology 114:255- 270. 
398

399

400

401

402

403

404

405

406

407

408

409

410

411

412

413

414

415

416

417

418

419

420

421

422

423

424

425

426

427

Schmid H, Cohen CD, Henger A, Irrgang S, Schlondorff D, Kretzler M. 2003. Validation of endogenous controls for gene expression analysis in microdissected human renal biopsies. Kidney International 64:356e60.

Simmons EG, Roberts R. 1993. Alternaria themes and variations (73). Mycotaxon 48:109-140.

Simmons. 1969. Perfect states of Stemphylium. Mycologia 61(1):1-26.

Suzuki T, Higgins P, Crawford D. 2000. Control selection for RNA quantitation. BioTechniques 29(2):332-337.

Swart K, van Heemst D, Slakhorst M, Debets F, Heyting C. 2001. Isolation and characterization of sexual sporulation mutants of Aspergillus nidulans. Fungal Genetics and Biology 33(1):25-35.

\section{Turgeon BG, Bohlmann H, Ciuffetti LM, Christiansen SK, Yang G, Schäfer W, Yoder O.} 1993. Cloning and analysis of the mating type genes from Cochliobolus heterostrophus. Molecular and General Genetics 238(1-2):270-284.

Turgeon BG. 1998. Application of mating type gene technology to problems in fungal biology. Annual Review of Phytopathology 36:115-137.

Vandesompele J, De Preter K, Pattyn F, Poppe B, Van Roy N, De Paepe A, Speleman F. 2002. Accurate normalization of real-time quantitative RT-PCR data by geometric averaging of multiple internal control genes. Genome Biology 3:34.

Vannini BA, Vettraino A. 2000. Ulocladium chartarum as the causal agent of a leaf necrosis on Quercus pubescens. Forest Pathology 30(6):297-303.

Wang Q, Wang S, Xiong CL, James TY, Zhang XG. 2017. Mating-type genes of the anamorphic fungus Ulocladium botrytis affect both asexual sporulation and sexual reproduction. Scientific Reports 7:7932.

Whiteway M. 2009. Yeast mating: putting some fizz into fungal sex? Current Biology 19(6):R258-R260.

Wik L, Karlsson M, Johannesson H. 2008. The evolutionary trajectory of the mating-type (mat) genes in Neurospora relates to reproductive behavior of taxa. BMC Evolutionary Biology 8:109.

Zitter T, Hsu L. 1990. A leaf spot of cucumber caused by Ulocladium cucurbitae in New York. Plant Disease 74(10):824-827. 
428 Zonneveld BJ. 1988. Effect of carbon dioxide on fruiting in Aspergillus nidulans. Transactions 429 of the British Mycological Society 91(4):625-629. 
Figure 1

Average expression stability values $(M)$ and ranking of control genes under different temperature $(A)$, medium $(B)$, photoperiod $(C)$ and $\mathrm{CO}_{2}(D)$ treatments.

A lower $\mathrm{M}$ value indicates more stable expression.

A

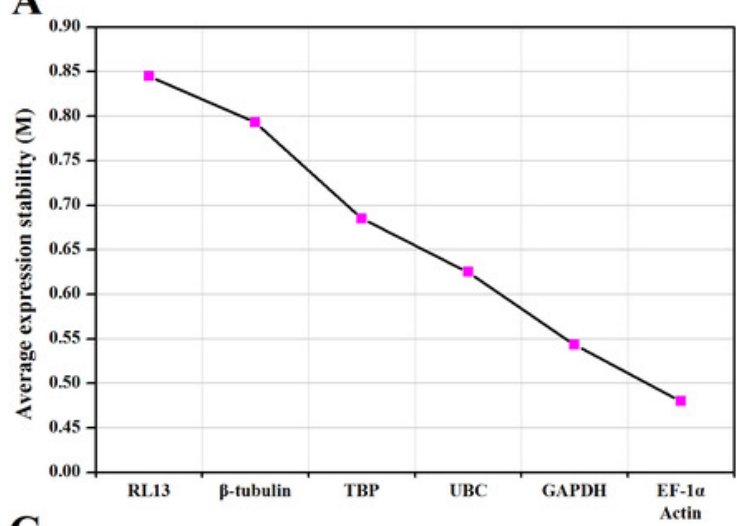

C

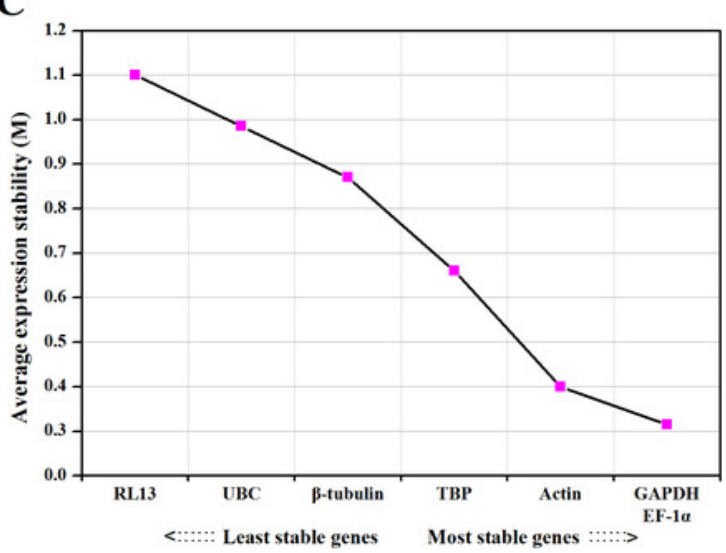

B

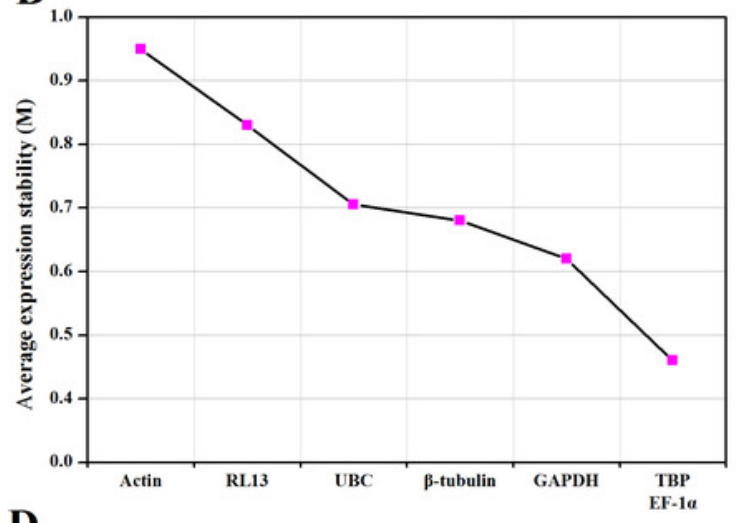

D

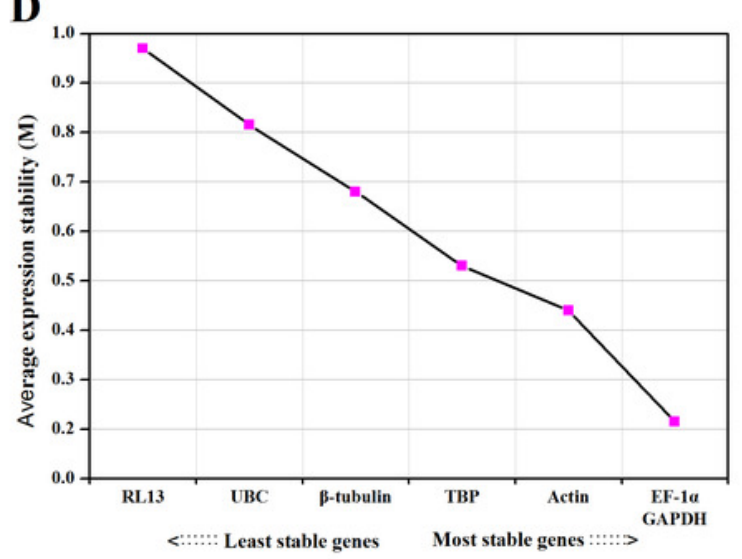


Figure 2

Pairwise variation $(V)$ of control genes under different temperature (A), medium (B), photoperiod $(\mathrm{C})$ and $\mathrm{CO}_{2}(\mathrm{D})$ treatments.

The pairwise variation $\left(V_{n} / V_{n+1}\right)$ was analyzed between the normalization factors $\mathrm{NF}_{n}$ and $\mathrm{NF}_{\mathrm{n}+1}$ to determine the optimal number of control genes for normalization.

A

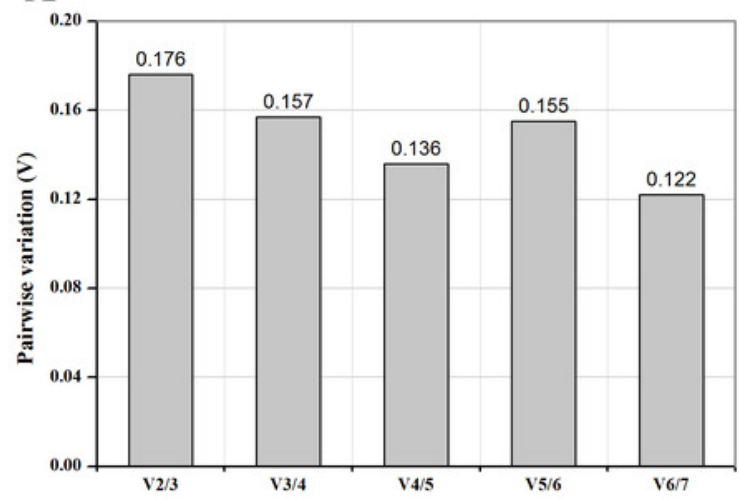

C

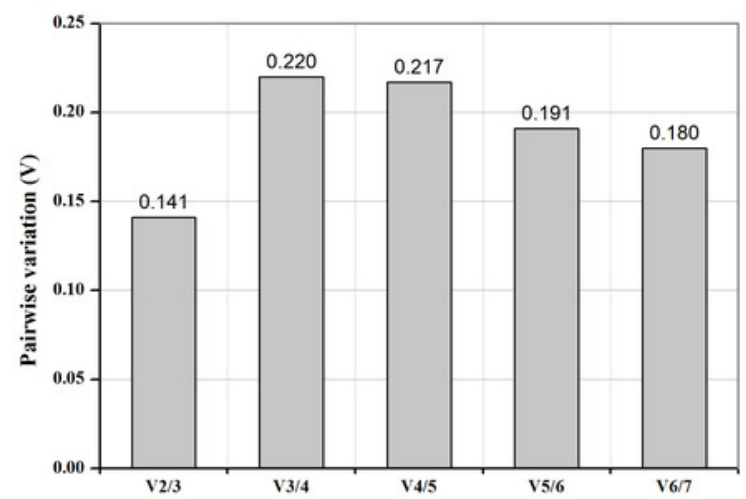

B

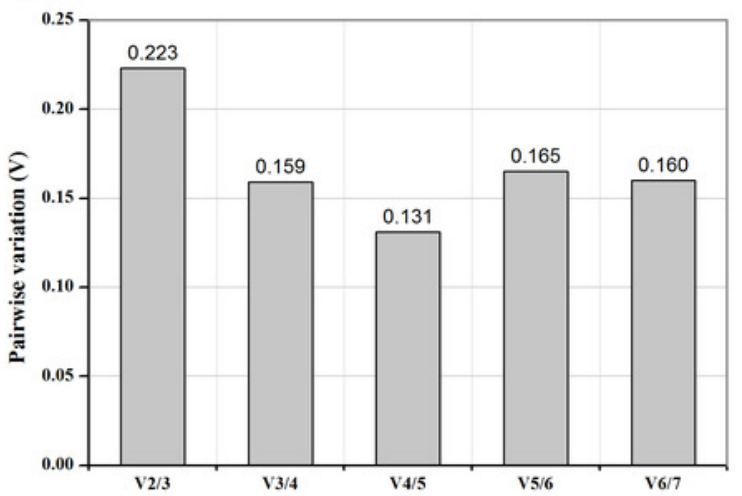

D

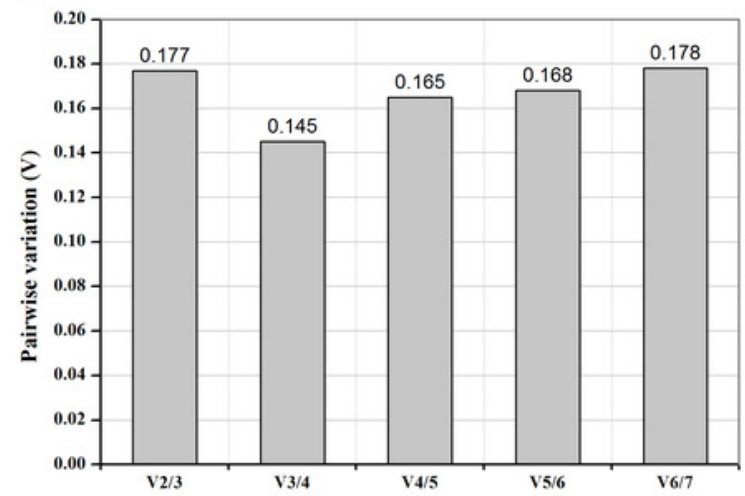


Figure 3

Expression levels of the MAT1-1-1 and MAT1-2-1 genes under different temperatures.

Sb: Expression levels of the MAT1-1-1 and MAT1-2-1 genes in Stemphylium botryosum.

Different letters indicate significant differences $(P<0.05)$. Error bars represent standard errors.

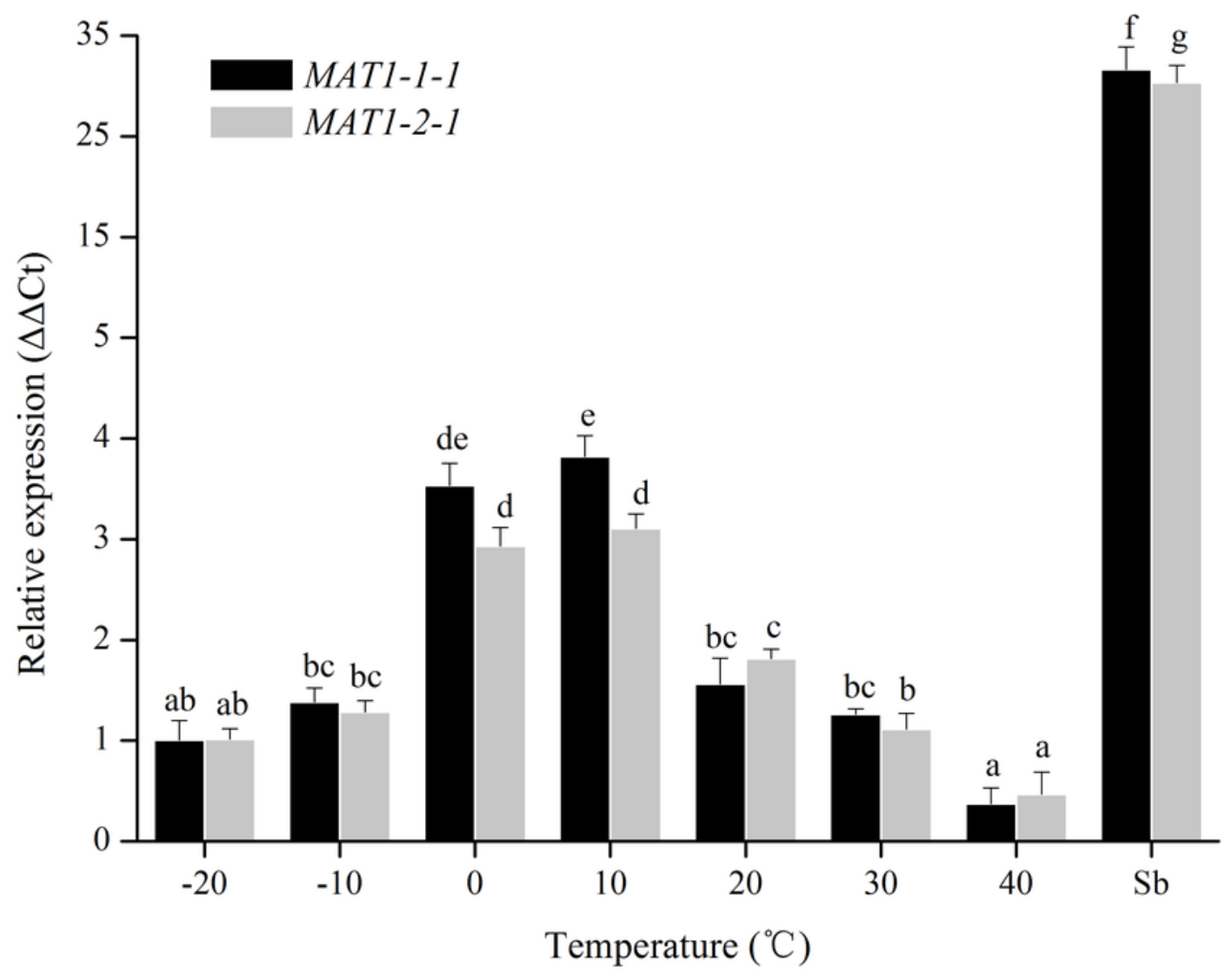


Figure 4

Expression levels of the MAT1-1-1 and MAT1-2-1 genes on different culture medias (CM, OA, HAY, PCA, PDA and V8).

Sb: Expression levels of the MAT1-1-1 and MAT1-2-1 genes in Stemphylium botryosum.

Different letters indicate significant differences $(P<0.05)$. Error bars represent standard errors.

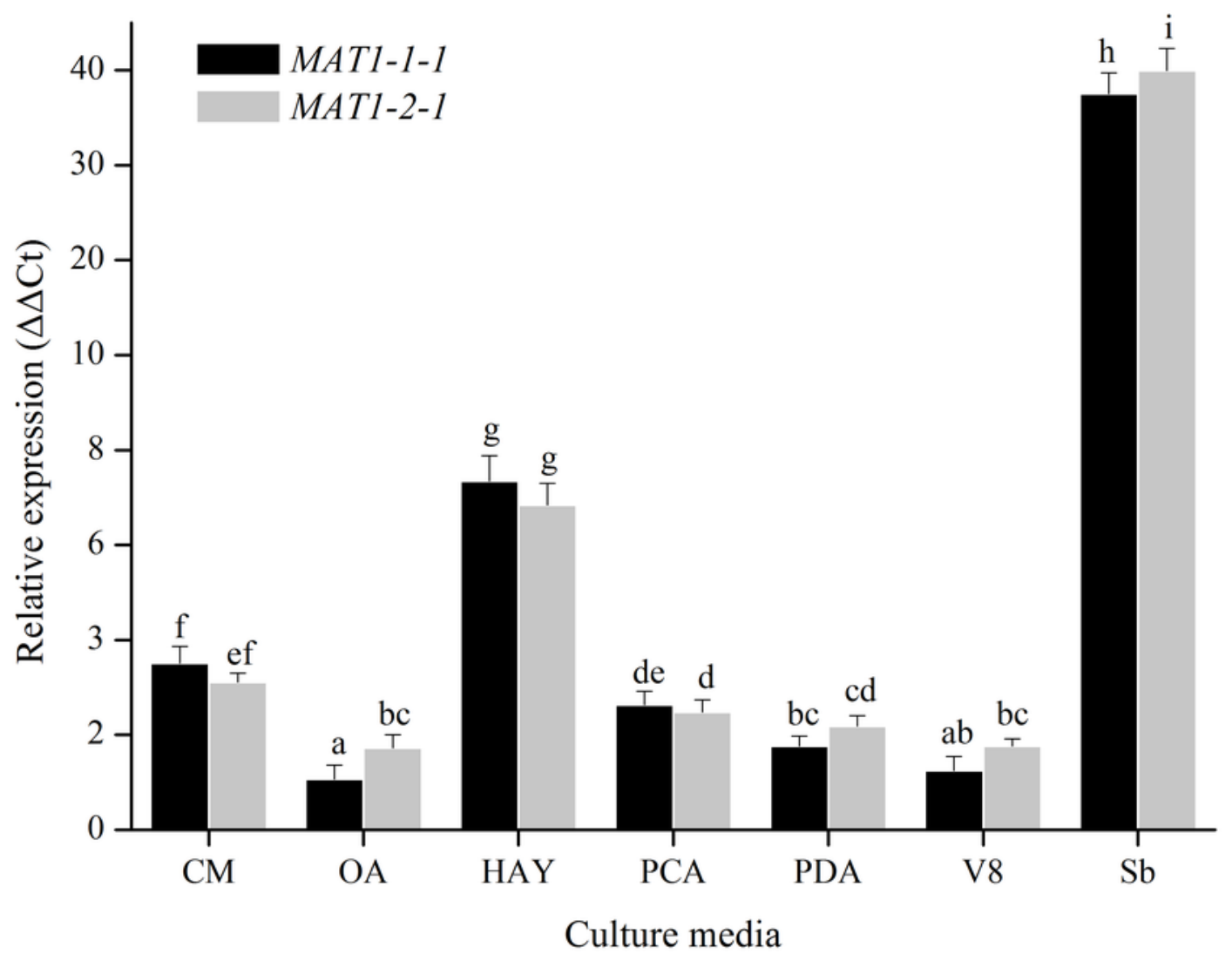




\section{Figure 5}

Expression levels of the MAT1-1-1 and MAT1-2-1 genes under different photoperiods (24h light, 24h dark, 12h light/12h dark, 10h light/14h dark and 8h light/16h dark).

Sb: Expression levels of the MAT1-1-1 and MAT1-2-1 genes in Stemphylium botryosum.

Different letters indicate significant differences $(P<0.05)$. Error bars represent standard errors.

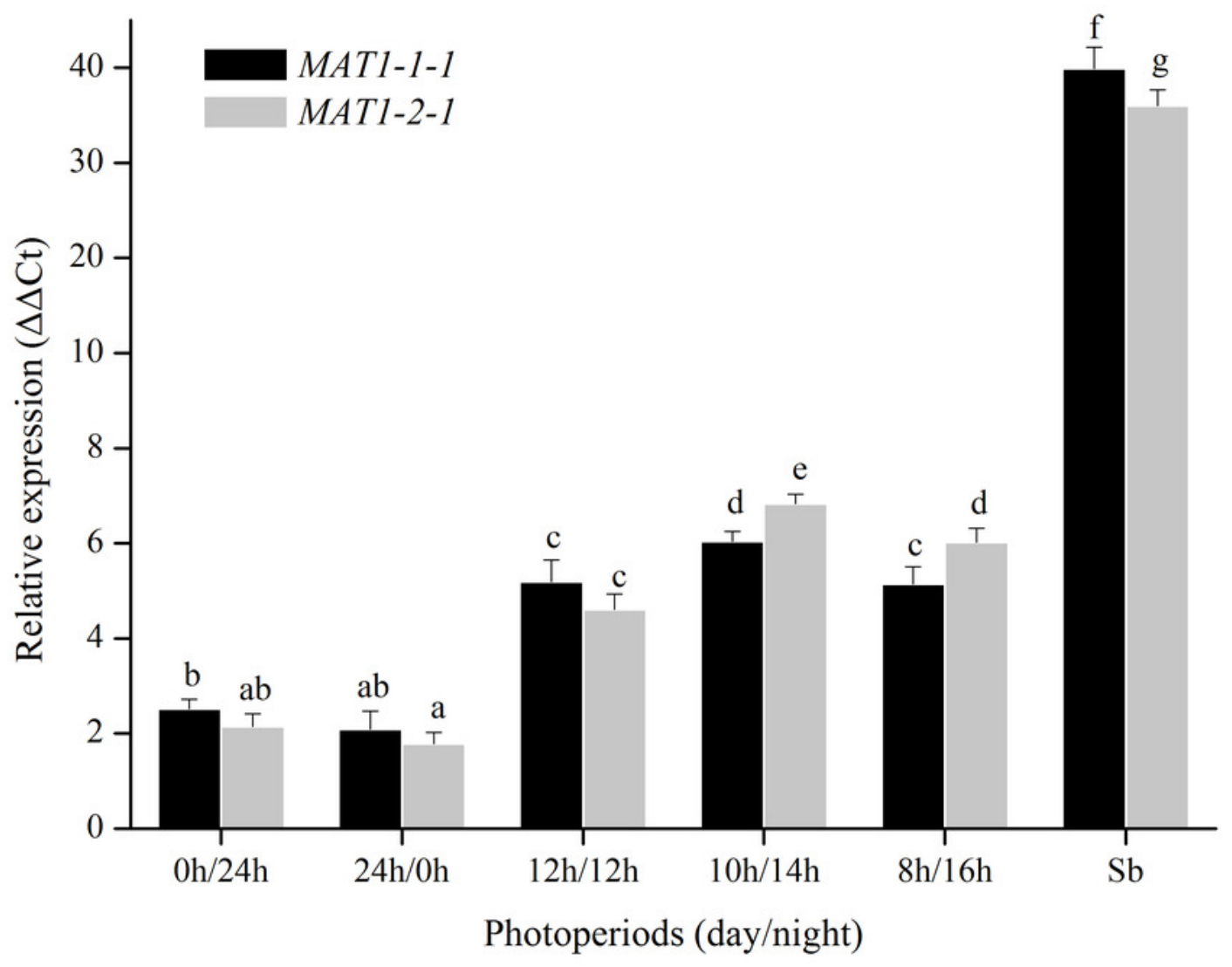




\section{Figure 6}

Expression levels of the MAT1-1-1 and MAT1-2-1 genes under different $\mathrm{CO}_{2}$ concentrations $(0.03 \%, 0.5 \%, 1 \%, 5 \%, 10 \%, 15 \%$ and $20 \%)$.

$\mathrm{Sb}$ : Expression levels of the MAT1-1-1 and MAT1-2-1 genes in Stemphylium botryosum.

Different letters indicate significant differences $(P<0.05)$. Error bars represent standard errors.

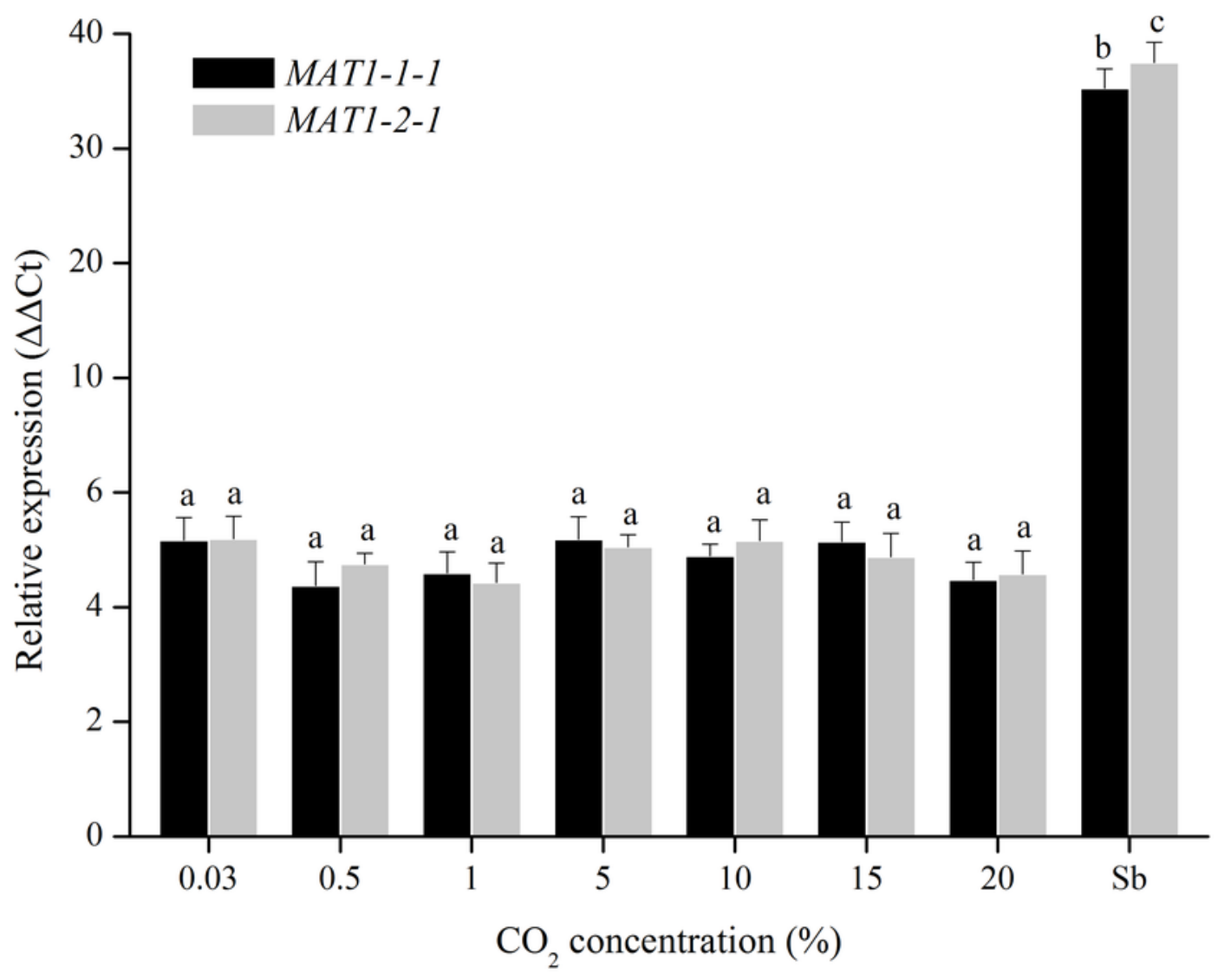

